\title{
Papers
}

\section{Systematic review of clinical effectiveness of pressurised metered dose inhalers versus other hand held inhaler devices for delivering $\beta_{2}$ agonists bronchodilators in asthma}

\author{
Felix S F Ram, John Wright, David Brocklebank, John E S White on behalf of the National Health \\ Technology Assessment Inhaler Review Group
}

\begin{abstract}
Objectives To determine the clinical effectiveness of pressurised metered dose inhalers compared with other hand held inhaler devices for delivering short acting $\beta_{2}$ agonists in stable asthma.

Design Systematic review of randomised controlled trials.

Data sources Cochrane Airways Group specialised trials database (which includes hand searching of 20 relevant journals), Medline, Embase, Cochrane controlled clinical trials register, pharmaceutical companies, and bibliographies of included trials. Trials All trials in children or adults with stable asthma that compared the pressurised metered dose inhaler (with or without a spacer device) against any other hand held inhaler device containing the same $\beta_{2}$ agonist.
\end{abstract}

Results 84 randomised controlled trials were included. No differences were found between the pressurised metered dose inhaler and any other hand held inhaler device for lung function, blood pressure, symptoms, bronchial hyperreactivity, systemic bioavailability, inhaled steroid requirement, serum potassium concentration, and use of additional relief bronchodilators. In adults, pulse rate was lower in those using the pressurised metered dose inhaler compared with those using Turbohaler (standardised mean difference $0.44,95 \%$ confidence interval 0.05 to 0.84); patients preferred the pressurised metered dose inhaler to the Rotahaler (relative risk $0.53,95 \%$ confidence interval 0.36 to 0.78 ); hydrofluoroalkane pressurised metered dose inhalers reduced the requirement for rescue short course oral steroids (relative risk 0.67, 0.49 to 0.91 ).

Conclusions No evidence was found to show that alternative inhaler devices are more effective than standard pressurised metered dose inhalers for delivering acting $\beta_{2}$ agonist bronchodilators in asthma. Pressurised metered dose inhalers remain the most cost effective delivery devices.

\section{Introduction}

Inhalation of bronchodilators and corticosteroids is the mainstay of treatment for patients with asthma Many inhaler devices and drug combinations are now available, and competing promotional claims can confuse both prescribers and patients. The costs of the drug used in specific devices differs greatly, and the annual cost to the NHS for asthma drugs is over $£ 500 \mathrm{~m}{ }^{1}$ National and international guidelines are inconsistent in their recommendations for prescribing inhaler devices in different age groups. ${ }^{23}$ None is explicitly evidence based, and there has been no systematic review of published trials.

We conducted a systematic review to determine the clinical effectiveness of the standard chlorofluorocarbon containing pressurised metered dose inhaler compared with other hand held inhaler devices, including chlorofluorocarbon-free pressurised metered dose inhalers delivering short acting $\beta_{2}$ agonist bronchodilators in patients with stable asthma.

\section{Methods}

Identification and selection of trials

We identified trials published from 1966 to December 2000 by computerised searches of the Cochrane Airways Group trials database, which includes Medline, Embase, CINAHL, and hand searching of 20 relevant journals and proceedings of three respiratory societies, and reviews of the bibliographies of included trials (www.ncchta.org/execsumm/summ526.htm). We also independently searched the electronic databases (Medline, Embase, and CINAHL) and 17 online respiratory websites to decrease the chance of missing relevant trials. We included citations in any language. We also contacted the pharmaceutical companies that manufacture inhaled asthma drugs and searched the reference lists of trials included in this review for further studies.

The results of the computerised search were independently reviewed by two reviewers. Any potentially relevant articles were obtained in full. The full text of potentially relevant articles was reviewed

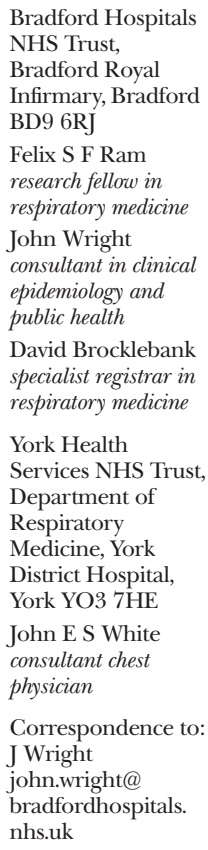

BMJ 2001;323:1-7 


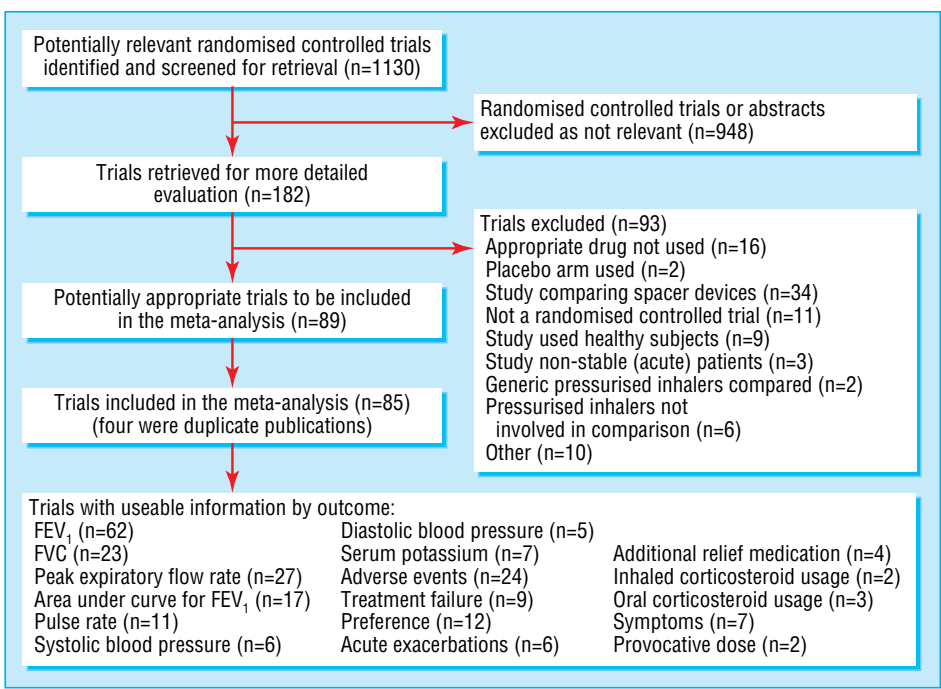

Fig 1 QUORUM trial flow results

independently by the two reviewers. Disagreement was resolved by third party adjudication.

\section{Trial characteristics}

We included only randomised controlled trials of short acting $\beta_{2}$ agonists. Trials could be laboratory, hospital, or community based. Trials were included if they compared clinical outcomes of a single drug delivered by standard pressurised metered dose inhalers (with or without a spacer device) against any other hand held device. Trials that compared different doses of inhaled drug and those that used challenge testing were also included. We included trials in both children and adults.

We looked at the following outcomes: lung function, quality of life measures, symptom scores, drugs for additional relief, steroid requirement, nocturnal awakening, acute exacerbation, days off work or school, treatment failure, patient compliance, patient preference, adverse effects, bronchial hyperreactivity, and systemic bioavailability. For trials using cumulative dosing schedules ${ }^{4-16}$ we used data that were generated after the administration of the last cumulative dose.

\section{Data abstraction and assessment of validity}

Two reviewers independently extracted details of each trial (intervention, duration, participants, design, quality, and outcome measures) directly into tables. Disagreement was resolved by consensus. We contacted the first authors of the included studies as necessary to provide additional information or data for their studies. We assessed internal validity of included trials using the Jadad ${ }^{17}$ and Cochrane scales. ${ }^{18}$

\section{Analysis of data}

We analysed the data using Review Manager (version 4.1.1) statistical software. ${ }^{18}$ For the meta-analysis, we used weighted mean differences for measures on the same scales (for example, forced expiratory volume in one second) or standardised mean differences for outcomes that used different scales (for example, symptoms).

The pressurised metered dose inhaler was compared with each of the different hand held inhaler devices. Each of these device comparisons was further separated into the different trial designs, duration, and the method of reporting (mean absolute values, percentage change from baseline, and absolute change from baseline). Trials were analysed separately for children and adults.

Twenty trials that examined pulmonary function variables early (15-45 minutes) rather than late (hours) after administration of bronchodilator were reported separately. This is because the early and late effects of $\beta_{2}$ bronchodilators may be different, especially as these compounds have a short half life and short duration of effect.

We tested heterogeneity between trials using $\chi^{2}$ tests. As long as statistical heterogeneity did not exist, we used a fixed effects model to calculate summary results and 95\% confidence intervals. If heterogeneity occurred, we planned subgroup analyses beforehand to explore possible reasons for heterogeneity. These subgroups included quality of the trial, severity of asthma, type of $\beta_{2}$ bronchodilator, and use of spacer device with pressurised metered dose inhaler. Publication or selection bias was tested by preparing funnel plots. $^{19}$

\section{Results}

The electronic search yielded 1130 citations: 40 references were found in Embase, Medline, CINAHL, and online respiratory journal databases, 1063 citations came from the Cochrane Airways Group register (fig 1). An additional 27 references were added from bibliographic searching of included trials. Of the 1130 abstracts, 181 trials were identified by two reviewers as potentially suitable for inclusion. On scanning the full text of these 181 trials, 92 were excluded (www.ncchta.org/execsumm/summ526.htm). Disagreements over inclusion arose in five papers and were resolved after discussion with the third reviewer. Eighty nine papers provided 84 trials (see www.ncchta.org/execsumm/summ526.htm for details) that were included in the review (with nine trials being duplicate publications of trials already included). ${ }^{4-16}{ }^{20-86}$ Four of the included trials ${ }^{748-85}$ reported more than one trial in their paper or had additional independent trial arms that met our inclusion criteria and were therefore analysed as separate trials. We wrote to 78 authors of the 80 included trials for further information and received 34 replies.

\section{Study characteristics}

There were 45 single dose trials, 16 long term trials, and 17 cumulative dosing trials; 62 trials used a crossover design and 10 a parallel design. Six trials used different or double dosing schedules and nine were challenge testing trials. Thirteen trials were in children. Some trials could be listed in more than one category.

The oldest included trial was published in 1977. The doses of $\beta_{2}$ agonist used in the included trials varied widely. In 64 trials of salbutamol, doses ranged from $100 \mu \mathrm{g}$ in single dose trials up to $4200 \mu \mathrm{g}$ in cumulative dose trials. In 15 trials of terbutaline doses ranged from $0.25 \mathrm{mg}$ (single dose) to $4.0 \mathrm{mg}$ (cumulative dose), and in five trials of fenoterol, single doses ranged from $200 \mu \mathrm{g}$ to $600 \mu \mathrm{g}$.

Seventy one trials (with 67 references) were in adults ${ }^{4-1623-62}{ }^{73-86}$ and 13 in children. ${ }^{20-22}$ 63-72 Most trials were in patients with mild to moderate asthma, as 
Table 1 Non-significant outcomes in trials comparing pressurised metered dose inhaler with other inhaler devices

\begin{tabular}{|c|c|}
\hline Trial design/Device & Non-significant outcomes (№ of trials and reference Nos) \\
\hline \multicolumn{2}{|l|}{ Crossover } \\
\hline Turbohaler & 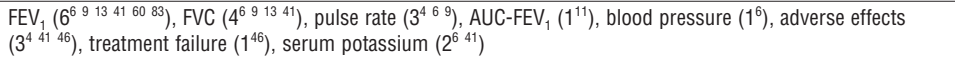 \\
\hline Diskhaler & PEFR $\left(1^{39}\right)$, adverse effects $\left(1^{39}\right)$ \\
\hline HFA-pressurised metered dose inhaler & 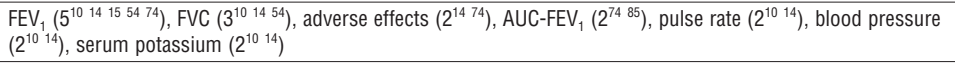 \\
\hline Rotahaler & $\begin{array}{l}\text { FEV }\left(8^{58} 8121640516276\right) \text {, FVC }\left(3^{16} 4062\right) \text {, PEFR }\left(4^{263638}{ }^{62}\right) \text {, AUC-FEV } 1\left(2^{4076}\right) \text {, adverse effects }\left(2^{3876}\right) \text {, } \\
\text { exacerbations }\left(1^{8}\right)\end{array}$ \\
\hline Spiros & $\operatorname{FEV}_{1}\left(1^{84}\right)$, FVC $\left(1^{84}\right)$, AUC-FEV ${ }_{1}\left(1^{84}\right)$, PEFR $\left(1^{14}\right)$, pulse rate $\left(1^{84}\right)$, blood pressure $\left(1^{14}\right)$, serum potassium $\left(1^{84}\right)$ \\
\hline Spinhaler & $\mathrm{FEV}_{1}\left(1^{31}\right), \mathrm{FVC}\left(1^{31}\right)$ \\
\hline Easyhaler & 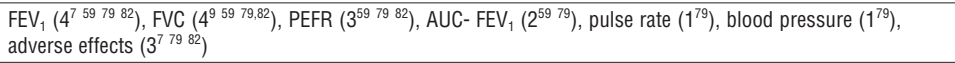 \\
\hline Multidose powder inhaler & 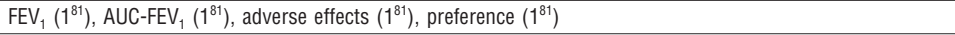 \\
\hline Clickhaler & $\mathrm{FEV}_{1}\left(1^{77}\right)$, adverse effects $\left(1^{17}\right)$ \\
\hline Gentlehaler & $\operatorname{FEV}_{1}\left(1^{44}\right)$, FVC $\left(1^{44}\right)$, PEFR $\left(1^{14}\right)$ \\
\hline Autohaler & $\operatorname{FEV}_{1}\left(1^{61}\right)$, FVC $\left(1^{61}\right)$, PEFR $\left(1^{161}\right)$ \\
\hline \multicolumn{2}{|l|}{ Parallel } \\
\hline $\begin{array}{l}\text { Powder inhaler or HFA-pressurised metered dose } \\
\text { inhaler }\end{array}$ & 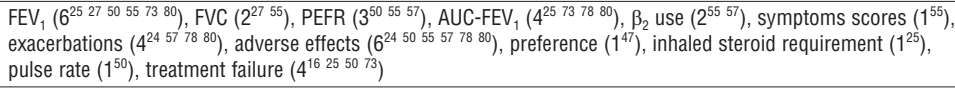 \\
\hline \multicolumn{2}{|l|}{ Challenge } \\
\hline $\begin{array}{l}\text { Powder inhaler or HFA-pressurised metered dose } \\
\text { inhaler }\end{array}$ & $\mathrm{FEV}_{1}\left(4^{23}{ }^{4364}{ }^{75}\right), \mathrm{FVC}\left(1^{43}\right), \mathrm{PD}_{20}-\mathrm{FEV}_{1}\left(2^{3281}\right)$ \\
\hline \multicolumn{2}{|l|}{ Different doses } \\
\hline $\begin{array}{l}\text { Powder inhaler or HFA-pressurised metered dose } \\
\text { inhaler }\end{array}$ & $\mathrm{FEV}_{1}\left(5^{28} 33495255\right)$, PEFR $\left(1^{58}\right)$, preference $\left(1^{28}\right)$, symptoms $\left(1^{33}\right)$ \\
\hline
\end{tabular}

defined by a baseline forced expiratory volume in one second $>50 \%$ of predicted.

\section{Data synthesis}

Most of the trials were double blinded using double dummy technique and most had adequate concealment of allocation. All trials were of good methodological quality with a Cochrane score above B and Jadad score greater than 3. Four of the included trials were reported as abstracts with insufficient information for scoring. ${ }^{29} 607585$

Most trials reported continuous outcomes as mean values after giving bronchodilators. However, 10 trials reported the mean maximum values after bronchodilator. ${ }^{73-82}$ We therefore did a sensitivity analysis (excluding these 10 trials) to find whether the results were different. In all cases, the results were not different with or without the inclusion of these trials.
For the 62 crossover trials, we had planned to use only the first arm data in our analysis. These data were reported by only 10 trials. However, with these 10 trials, we were able to use inverse variance pooling in order to test the effect of our software treating data from crossover trials as parallel data. The results were the same when comparing individual patient data with group means.

Thresholds for clinically important results of pulmonary function tests are often arbitrary. However, from the range of values that the trial researchers used, a guide would be $15-30 \mathrm{l} / \mathrm{min}$ or $7.5 \%$ to $20 \%$ for peak expiratory flow rate and 0.2 or $15 \%$ for forced expiratory volume in one second.

We found no significant differences in children or adults between the standard pressurised metered dose inhaler and any of the other 10 hand held inhaler

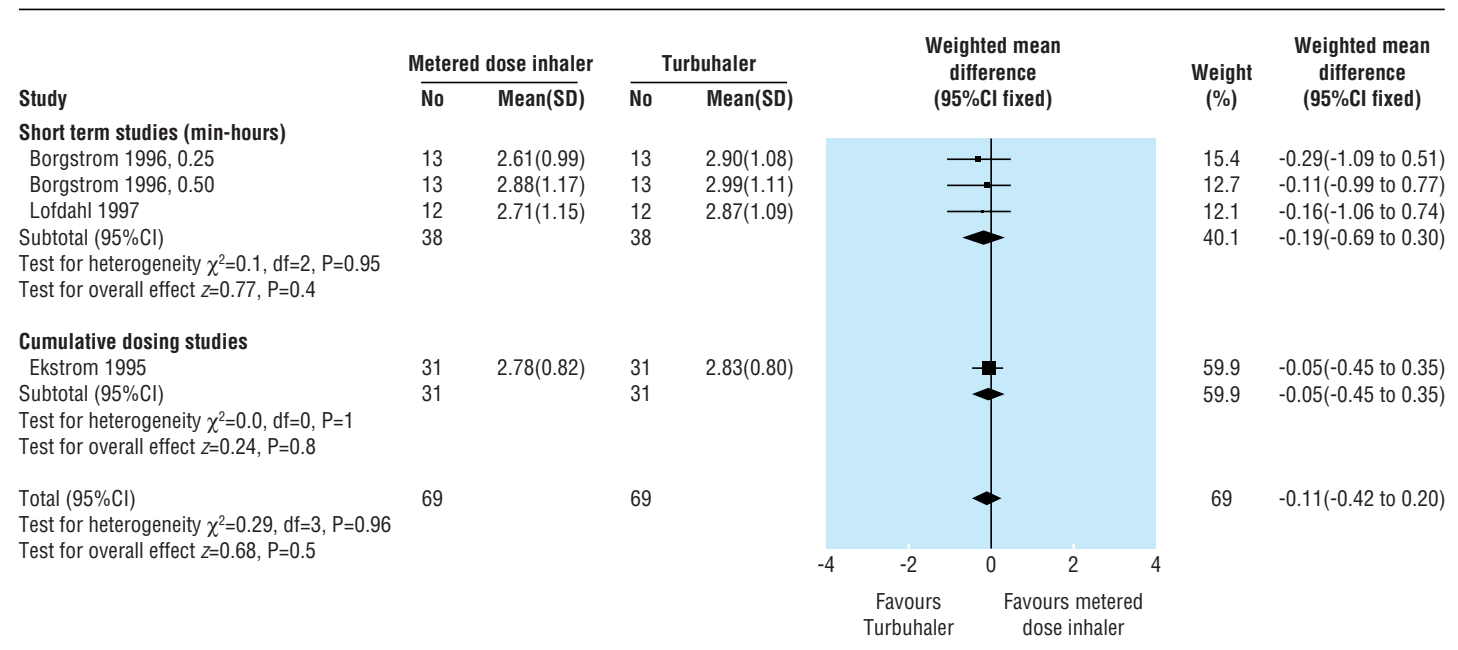

Fig 2 Forced expiratory volume in one second values for patients in trials comparing pressurised metered dose inhalers with Turbohaler 
Table 2 Significant outcomes found in more than one trial

\begin{tabular}{|c|c|c|c|c|c|}
\hline Inhaler device & Outcome (favoured device) & $\begin{array}{l}\text { No of trials and } \\
\text { reference Nos }\end{array}$ & Type of trial (No of patients) & Effect size $(95 \% \mathrm{CI})$ & $P$ value \\
\hline \multicolumn{6}{|l|}{ Adults } \\
\hline Turbohaler & $\begin{array}{l}\text { Pulse rate (higher with } \\
\text { Turbohaler) }\end{array}$ & $3^{469}$ & $\begin{array}{l}\text { Cumulative dosing crossover } \\
\text { (104) }\end{array}$ & $\mathrm{SMD}=0.44(0.05$ to 0.84$)$ & 0.03 \\
\hline Rotahaler & $\begin{array}{l}\text { Patient preference (metered } \\
\text { dose inhaler) }\end{array}$ & $3^{263538}$ & $\begin{array}{l}\text { Crossover trials: } 2 \text { long term, } \\
1 \text { short term (156) }\end{array}$ & Odds ratio $=3.10$ (1.60 to 6.01$)$ & 0.0008 \\
\hline \multirow{2}{*}{$\begin{array}{l}\text { HFA-pressurised metered } \\
\text { dose inhaler }\end{array}$} & \multirow{2}{*}{$\begin{array}{l}\text { Oral steroid requirement } \\
\text { (lower with HFA inhaler) }\end{array}$} & \multirow[t]{2}{*}{$3^{7380}$} & \multirow[t]{2}{*}{ Long term parallel trials (519) } & Odds ratio $=0.57(0.37$ to 0.88$)$ & 0.01 \\
\hline & & & & NNT=9 (5.21 to 43.48) & \\
\hline \multicolumn{6}{|l|}{ Children } \\
\hline Rotahaler & $\begin{array}{l}\text { Patient preference (metered } \\
\text { dose inhaler) }\end{array}$ & $2^{65} 70$ & $\begin{array}{l}\text { Long term trials: } 1 \text { parallel, } \\
1 \text { crossover }(260)\end{array}$ & Odds ratio=2.63 (1.56 to 4.44$)$ & 0.0003 \\
\hline
\end{tabular}

$\mathrm{SMD}=$ standardised mean difference, $\mathrm{HFA}=$ hydrofluoroalkane, NNT=number needed to treat.

devices (Turbohaler, Diskhaler, hydrofluoroalkane pressurised metered dose inhaler, Rotahaler, Spiros, Easyhaler, multidose powder inhaler, Clickhaler, Gentlehaler, and Autohaler) for the following outcomes: forced expiratory volume in one second, forced vital capacity, peak expiratory flow rate, area under the curve for forced expiratory volume in one second, blood pressure, symptoms, bronchial hyperreactivity, systemic bioavailability, inhaled steroid requirement, serum potassium concentration, and use of additional relief bronchodilators (table 1). Figure 2 shows an example of the meta-analysis as Forrest plots. A complete set of Forrest plots is available on www.ncchta.org/execsumm/summ526.htm. No data were available for quality of life, patient compliance, nocturnal awakening, and days off work or school.

Six of the trials that used a 2 to 1 or larger dosing schedule $^{28} 4349525658$ did not show significantly different results and did not provide results that were different from trials that used a 1 to 1 dosing schedule.

Tables 2 and 3 show all outcome measures that were significant in one or more trials $(\mathrm{P}<0.05)$ and did not show any heterogeneity.

Five studies used spacer devices with the pressurised metered dose inhalers. ${ }^{2132} 335271$ There were no differences in the results of trials that used pressurised metered dose inhalers with and without spacer devices compared with alternative inhaler devices. However, this indirect subgroup comparison was not determined before the study and is therefore not a reliable method to assess the effectiveness of spacer devices.

\section{Discussion}

This large review of 84 trials and 14 outcome measures found no evidence that pressurised metered dose inhalers were any less effective than other inhaler devices for administering short acting $\beta_{2}$ agonists. The number of trials that could be combined in the meta-analysis was limited by inconsistencies in measurement and reporting of outcomes. Publication bias is a threat to the validity of most systematic reviews. However, there was no evidence of funnel plot asymmetry in any of the comparisons (fig 3).

A pitfall of crossover trials, such as those included in this review, is that the effects of the first treatment can carry over into the second treatment period, leading to an underestimation of the real difference between treatments. ${ }^{87}$ In the crossover trials included, treatment with short acting $\beta_{2}$ agonists did not seem to alter respiratory function (forced expiratory volume in one second) before treatment in the second arm, and if lung function differed by more than 10-15\% from baseline values the patient was excluded from the trial or the second arm visit rescheduled. ${ }^{58980}$ However, most trials included a washout period and patients were excluded if lung function differed by more than $10-15 \%$ from baseline.

\section{Notable findings}

Trials using 2 to 1 or greater dosing showed no clinical advantage over 1 to 1 dosing trials. Higher dosing schedules are often promoted by pharmaceutical companies to show clinical superiority of one inhaler device over another and to support prescribing recommendations. We found no evidence in support of these claims. A previous review of inhaler devices that considered the relation between clinical efficacy and lung deposition concluded that differences in drug deposition alone did not always explain corresponding differences in bronchodilatory responses among inhaler devices. ${ }^{88}$

Three trials found a higher pulse rate in patients using Turbohaler than those using a pressurised

Table 3 Significant outcomes found in only one trial

\begin{tabular}{|c|c|c|c|c|}
\hline Inhaler device & Outcome (favoured device) & Trial type (No of patients) & Effect size $(95 \% \mathrm{CI})$ & $P$ value \\
\hline \multicolumn{5}{|l|}{ Adults } \\
\hline Turbohaler & Preference (Turbohaler) & Long term paralle $\left.\right|^{47}(258)$ & $\mathrm{OR}=2.83(1.59$ to 5.03$)$ & $<0.0006$ \\
\hline Rotahaler & Pulse rate (Rotahaler) & Cumulative dosing crossover $^{16}(14)$ & $W M D=-5.5(-10.0$ to -0.96$)$ & 0.02 \\
\hline Multidose powder inhaler & Preference (metered dose inhaler) & Short term crossover ${ }^{81}(72)$ & $\mathrm{OR}=0.36(0.14$ to 0.93$)$ & 0.04 \\
\hline Spinhaler & $\mathrm{FEV}_{1}$ (metered dose inhaler) & Short term crossover ${ }^{31}(40)$ & WMD $=0.80$ (0.01 to 0.16$)$ & $<0.05$ \\
\hline Spinhaler & FVC (metered dose inhaler) & Short term crossover $^{31}(40)$ & WMD $=0.26$ (0.09 to 0.43$)$ & 0.002 \\
\hline \multicolumn{5}{|l|}{ Children } \\
\hline Turbohaler & Preference (Turbohaler) & Long term crossover $^{69}(114)$ & OR=3.27 (1.46 to 7.33$)$ & 0.004 \\
\hline Rotahaler & Peak expiratory flow (Rotahaler) & Long term crossover ${ }^{65}(86)$ & WMD=105.4 (59 to 150$)$ & $<0.0001$ \\
\hline Rotahaler & Exacerbations (Rotahaler) & Long term parallel ${ }^{70}(204)$ & $R R=0.52(0.28$ to 0.95$)$ & 0.034 \\
\hline
\end{tabular}

$\mathrm{OR}=0$ dds ratio, $\mathrm{WMD}=$ weighted mean difference, $\mathrm{RR}=$ relative risk. 
metered dose inhaler..$^{2123}{ }^{26}$ This would indicate greater systemic absorption with Turbohaler, although this did not translate into greater treatment effect.

Three trials found that adult patients preferred the pressurised metered dose inhaler to the Rotahaler. $^{26}{ }^{35} 38$ One trial in children ${ }^{69}$ and one in adults ${ }^{47}$ showed that patients preferred the Turbohaler. One trial showed that patients preferred the pressurised metered dose inhaler to the multidose dry powder inhaler. ${ }^{81}$ These results should be viewed with caution because of the potential for bias regarding blinding of new inhaler devices in clinical trials.

Long term parallel trials have shown that regular daily use of hydrofluoroalkane pressurised metered dose inhalers may reduce the requirement for short course oral steroids. ${ }^{73}$ However, this result may be biased because of inadequate randomisation in one trial. Confirmation from further trials is required.

\section{Further research}

Although we did not find significant differences for most outcomes, the confidence intervals could include clinically important differences. Our comparison of population means cannot show such clinically important differences for individual patients from different inhaler devices. Small changes in physiological measures such as pulmonary function will not necessarily be important in themselves, but rather in the impact they have on the symptoms and quality of life of the patient. ${ }^{89}$

Future trials should address the paucity of patient centred outcomes such as quality of life, adherence, nocturnal awakening, and days off work or school. Data on these outcomes were not available in this review. Further systematic reviews are needed to assess the effectiveness of pressurised metered dose inhalers with or without spacer devices and the effectiveness of training and education about use of inhaler devices.

\section{Conclusion}

We found no evidence that alternative inhaler devices are clinically more effective than pressurised metered dose inhaler for delivery of short acting $\beta_{2}$ bronchodilators. Therefore, pressurised metered dose inhaler or the cheapest inhaler device the patient can use adequately, should be prescribed as first line in all patients with stable asthma requiring short acting $\beta_{2}$ agonist bronchodilators.

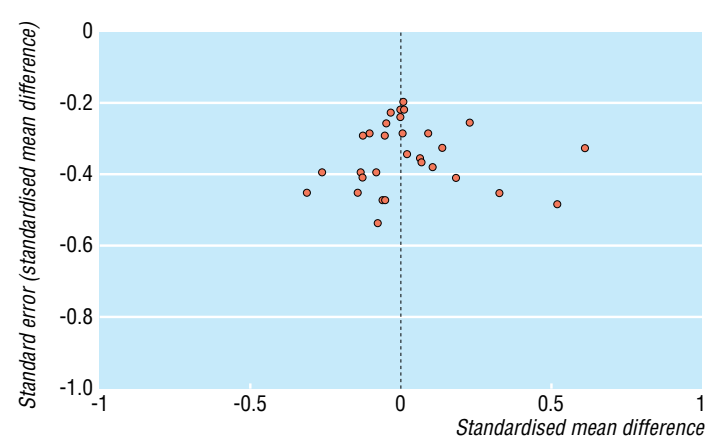

Fig 3 Example funnel plot for 31 trials (1290 participants) with data on forced expiratory flow volume in one second for pressurised metered dose inhaler and all other inhaler devices combined using standardised mean difference

\section{What is already known on this topic}

Many different inhaler devices are available for administration of short acting $\beta_{2}$ agonists in asthma

Current guidelines for their use are inconsistent and not evidence based

\section{What this study adds}

This systematic review found no evidence that alternative inhaler devices are more effective than pressurised metered dose inhalers for administering inhaled $\beta_{2}$ agonist bronchodilators

Pressurised metered dose inhalers (or the cheapest inhaler device) should be used as first line treatment in all patients with stable asthma who require $\beta_{2}$ agonists

This paper is based on a Cochrane review that is available in the Cochrane Library. As with all Cochrane reviews, the authors have committed to keep this review up to date.

The members of the National Health Technology Assessment Inhaler Review Steering Group are Felix Ram (research fellow in respiratory medicine, Bradford Hospitals NHS Trust), David Brocklebank (specialist registrar in respiratory medicine, Bradford Hospitals NHS Trust), John Wright (consultant in clinical epidemiology and public health, Bradford Hospitals NHS Trust), Chris Cates (general practitioner and Cochrane editor, Bushey, Hertfordshire), John E S White (consultant physician, York Health Services NHS Trust), Martin Muers (consultant physician, United Leeds Teaching Hospitals), Graham Douglas (consultant physician, Aberdeen Royal Hospitals), Linda Davies (senior research fellow, University of York), Dave Smith (research fellow, University of York), and Peter Barry (consultant paediatrician, Leicester Royal Infirmary).

We thank the following groups and individuals for their help: Cochrane Airways Review Group staff at St George's Hospital in London (Steve Milan, Karen Blackhall, Bettina Rueben, Toby Lasserson) for identifying trials and obtaining copies of papers; and Sheree Wellington for checking data abstractions and entry. We also thank all authors who provided further data from their trials.

Contributors: All members of the steering group participated in the research design and methods of the review. FSFR, $\mathrm{DB}$, and JW did the literature review, data extraction, and analysis and wrote the paper with JESW. JW chaired the steering group and is the guarantor.

Funding: NHS Research and Development Health Technology Assessment Programme.

Competing interests: None declared.

1 Neville RG, Pearson MG, Richards N, Patience J, Sondhi S, Wagstaff B, et al. A cost analysis on the pattern of asthma prescribing in the UK. Eur Respir J 1999;14:605-9.

2 British Thoracic Society. British guidelines on asthma management. Thorax 1997;52(suppl 1):S1-21.

3 American Thoracic Society. Standards for the diagnosis and care of patients with chronic obstructive pulmonary disease. Am J Respir Crit Care Med 1995;152:S77-120.

4 Bondesson E, Friberg K, Soliman S, Lofdahl CG. Safety and efficacy of a high cumulative dose of salbutamol inhaled via Turbuhaler or via a pressurized metered-dose inhaler in patients with asthma. Respir Med 1998:92:325-30.

5 Dirksen H, Groth S. Fenoterol inhalation powder as an alternative to treatment with the metered dose inhaler. Eur J Respir Dis 1983;64(suppl 130):48-53.

6 Ekstrom T, Andersson AC, Skedinger M, Lindbladh C, Stahl E. Dose potency relationship of terbutaline inhaled via Turbuhaler or via a pressurized metered dose inhaler. Ann Allergy Asthma Immunol 1995;74:32832.

7 Haahtela T, Vidgren M, Nyberg A, Korhonen P, Laurikainen K, Silvasti M. A novel multiple dose powder inhaler. Salbutamol powder and aerosol give equal bronchodilatation with equal doses. Ann Allergy 1994;72(2):178-82

8 Hetzel MR, Clark CG. Comparison of salbutamol Rotahaler with conventional pressurized aerosol. Clin Allergy 1977;7:563-8.

9 Johnsen CR, Weeke ER. Turbuhaler: a new device for dry powder terbutaline inhalation. Allergy 1988;43:393-5. 
10 Kleerup EC, Tashkin DP, Cline AC, Ekholm BP. Cumulative dose-response trial of non-CFC propellant HFA 134a salbutamol sulfate metered-dose inhaler in patients with asthma. Chest 1996;109:702-7.

11 Mellen A, Arvidsson P, Palmqvist M, Lotvall J. Equivalent bronchodilation with salbutamol given via pressurised metered-dose inhaler or Turbuhaler. Am J Respir Crit Care Med 1999;159(5 Pt 1):1663-5.

12 Morice AH, Peake MD, Allen MB, Campbell JH, Parry-Billings M. Evaluation of a novel salbutamol dry powder inhaler: clinical equivalence to a standard metered dose inhaler and in-use stability. Br J Clin Pharmacol 1996;42:658.

13 Persson G, Gruvstad E, Stahl E. A new multiple dose powder inhaler (Turbuhaler) compared with a pressurized inhaler in a trial of terbutaline in asthmatics. Eur Respir J 1988;1:681-4.

14 Ramsdell JW, Colice GL, Ekholm BP, Klinger NM. Cumulative dose response trial comparing HFA-134a albuterol sulfate and conventional CFC albuterol in patients with asthma. Ann Allergy Asthma Immunol 1998;81:593-9

15 Ruffin R, Mitchell C, Thompson P, Harle D, Cline A, Ekholm B. A placebo controlled comparison of the dose-response effects of salbutamol sulphate in chlorofluorocarbon (CFC) vs hydrofluoroalkane (HFA-134a) propellants in asthmatics. Am J Respir Crit Care Med 1995;151:A58.

16 Svedmyr N, Lofdahl C-G, Svedmyr K. The effect of powder aerosol compared to pressurized aerosol. Eur J Respir Dis 1982;63(suppl 119):81-8.

17 Jadad AR, Moore RA, Carrol D, Jenkinson C, Reynolds DJ, Gavaghan DJ, et al. Assessing the quality of reports of randomized clinical trials: Is blinding necessary? Controlled Clin Trials 1996;17(1):1-12.

18 Clarke M, Oxman AD, eds. Cochrane reviewers' handbook 4.0. In: Review manager (RevMan) [computer program]. Version 4.0. Oxford: Cochrane Collaboration, 1999.

19 Egger M, Davey Smith G, Schneider M, Minder C. Bias in meta-analyses detected by a simple graphical test. BMJ 1997;315:629-34.

20 Svenonius E, Arborelius M, Wiberg R, Stahl E, Svenonius M. A comparison of terbutaline inhaled by Turbuhaler and by a chlorofluorocarbon (CFC) inhaler in children with exercise-induced asthma. Allergy 1994;49:408-12.

21 3M Health Care. Four week safety and efficacy trial of Airomir inhaler and CFC-salbutamol inhaler in children with asthma. Loughborough: 3M Health Care (unpublished data in file 1141-SILV).

22 Ahlstrom H, Svenonius E, Svensson M. Treatment of asthma in pre-school children with inhalation of terbutaline in Turbuhaler compared with nebuhaler. Allergy 1989;44:515-8.

23 Anderson PB, Stahl E, Hansen NCG. Terbutaline via Turbuhaler is effective in reversing metacholine-induced bronchoconstriction. J Clin Res 1998;1:49-54

24 Baumgarten CR, Dorow P, Weber HH, Gebhardt R, Kettner J, Sykes AP. Equivalence of as-required salbutamol propelled by propellants 11 and 12 or HFA 134-a in mild to moderate asthmatics. Respir Med 2000;94(suppl B):S17-21.

25 Bleecker ER, Tinkleman DG, Ramsdell J, Ekholm BP, Klinger NM, Colice GL, et al. Proventil HFA provides bronchodilation comparable to ventolin over 12 weeks of regular use in asthmatics. Chest 1998;113:283-9.

26 Boye K. A comparison of fenoterol powder capsules and fenoterol metered dose spray in bronchial asthma. Eur J Respir Dis 1983;64(suppl 130):9-11.

27 Bronsky E, Bucholtz GA, Busse WW, Chervinsky P, Condemi J, Ghafouri MA, et al. Comparison of inhaled albuterol powder and aerosol in asthma.J Allergy Clin Immunol 1987;79:741-7.

28 Chapman KR, Friberg K, Balter MS, Hyland RH, Alexander M, Abboud RT, et al. Albuterol via Turbuhaler versus albuterol via pressurized metered-dose inhaler in asthma. Ann Allergy Asthma Immunol 1997;78:5963.

29 Cohen RM, Plescow WW, Webb DR, Devorin DJ, Rooklin AR, Barnhart $\mathrm{FH}$, et al. Albuterol in HFA propellant (ALB-HFA) $180 \mathrm{mcg}$ QID is comparable in safety and efficacy to albuterol in CFC propellant (ALB-CFC) $180 \mathrm{mcg}$ QID in adolescent and adult patients with asthma. J Allergy Clin Immunol 1999;103:S128(489).

30 Dockhorn RJ, Wagner DE, Burgess GL, Hafner KB, Letourneau K, Colice GL, et al. Proventil HFA provides protection from exercise-induced bronchoconstriction comparable to proventil and ventolin. Ann Allergy Asthma Immunol 1997;79:85-8.

31 Duncan D, Paterson IC, Harris D, Crompton GK. Comparison of the bronchodilator effects of salbutamol inhaled as a dry powder and by conventional pressurised aerosol. Br Clin Pharm 1977;4:669-71.

32 Giannini D, Di Franco A, Bacci E, Dente F, Taccola M, Vagaggini B, et al. The protective effect of salbutamol inhaled using different devices on methacholine bronchoconstriction. Chest 2000;117:1319-23.

33 Golish J, Curtis-McCarthy P, McCarthy K, Kavuru M, Wagner W, Beck G, et al. Albuterol delivered by metered-dose inhaler (MDI), MDI with spacer and Rotahaler device-a comparison of efficacy and safety. J Asthma 1998;35:373-9.

34 Harris R, Rothwell RP. A comparison between aerosol and inhaled powder administration of fenoterol in adult asthmatics. NZ Med J 1981;94:421-2.

35 Hartley JP, Nogrady SG, Gibby OM, Seaton A. Bronchodilator effects of dry salbutamol powder administered by Rotahaler. Br J Clin Pharmacol 1977;4:673-5.

36 Hartley JPR, Nogrady SG, Seaton A. Long-term comparison of salbutamol powder with salbutamol aerosol in asthmatic out-patients. $\mathrm{Br}$ J Dis Chest 1979;73:271-6.

37 Jackson L, Stahl E, Holgate ST. Terbutaline via pressurised metered dose inhaled (P-MDI) and Turbuhaler in highly reactive asthmatic patients. Eur Respir J 1994;7(9):1598-601.

38 Kiviranta K. Fenoterol inhalation powder and aerosol in the treatment of asthma. Allergy 1985;40:305-7.
39 Kou M, Kumana CR, Lauder IJ, Lam WK, Chan JCK. Bronchodilator responses to salbutamol using Diskhaler versus metered-dose inhaler. JAsthma 1998;35(6):505-11

40 Latimer KM, Roberts R, Dolovich J, Hargreave FE. Salbutamol: comparison of bronchodilating effect of inhaled powder and aerosol in asthmatic subjects. Can Med Assoc J 1982;127:857-9.

41 Lofdahl CG, Andersson L, Bondesson E Carlsson LG, Friberg K, Hedner $\mathrm{J}$, et al. Differences in bronchodilating potency of salbutamol in Turbuhaler as compared with pressurized metered-dose inhaler formulation in patients with reversible airway obstruction. Eur Respir J 1997;10:2474-8.

42 Maesen FP, Smeets JJ, Bersen R, Cornelissen PJ. Ipratropium bromide (Atrovent) as inhalation powder. A double-blind trial of comparison with ipratropium as a pressure aerosol in patients with reversible airways obstruction. Allergy 1986;41:37-42.

43 Mathieu M, Goldman M, Lellouche N, Sartene R. Kinetics of action of salbutamol inhaled from a metered dose inhaler (MDI) and a "diskhaler". Eur J Clin Pharmacol 1992;42:435-8.

44 Newman SP, Clarke SW. Bronchodilator delivery from Gentlehaler, a new low-velocity pressurized aerosol inhaler. Chest 1993;103:1442-6.

45 O'Callaghan C, Everard ML, Russell RIR, Bush A, Keeffe PO. Efficacy and safety of salbutamol delivered by a novel multidose dry powder inhaler (DPI) and a pressurized metered dose inhaler (MDI) in paediatric asthma. Eur Respir J 1997;16:126s

46 Osterman K, Norborg AM, Stahl E. A multiple dose powder inhaler (Turbuhaler) compared with a conventional aerosol. Allergy 1989;44:294-7.

47 Osterman K, Stahl E, Kallen A. Bricanyl Turbuhaler in the treatment of asthma: a six week multi-centre trial carried out in Sweden, the United Kingdom, Denmark, Norway and Finland. Eur Respir J 1991;4:175-9.

48 Parameswaran KN, Inman MD, Ekholm BP, Morris MM, Summers E, O'Byrne PM, et al. Protection against methacholine bronchoconstriction to assess relative potency of inhaled beta-2 agonists. Am J Respir Crit Care Med 1999;160:354-7.

49 Pover GM, Langdom CG, Jones SR, Fidler C. Evaluation of a breath operated powder inhaler. J Int Med Res 1988;16(3):201-3.

50 Salat D, Popov D, Sykes AP. Equivalence of salbutamol $200 \mu \mathrm{g}$ four times daily propelled by propellants 11 and 12 or HFA 134-a in mild to moderate asthmatics. Respir Med 2000;94(suppl B):S22-8.

51 Salorinne Y, Siren R. Ventilation effects of fenoterol powder and freon-propelled aerosol in patients with asthma. Eur J Respir Dis $1983 ; 130$ (suppl):6-8.

52 Selroos O, Lofroos AB, Pietinalho A, Riska H. Comparison of terbutaline and placebo from a pressurised metered dose inhaler and a dry powder inhaler in a subgroup of patients with asthma. Thorax 1994;49:1228-30.

53 Seppala O-P, Herrala J, Hedman J, Alanko K, Liipo K, Terho E, et al. The bronchoprotective efficacy of salbutamol inhaled from a new metereddose powder inhaler compared with a conventional pressurized metered-dose inhaler connected to a spacer. Respir Med 1998;92:578-83.

54 Taggart SC, Custovic A, Richards DH, Woodcock A. GR106642X: a new, non-ozone depleting propellant for inhalers. BMJ 1995;310:1639-40.

55 Tammivaara R, Aalto E, Lehtonen K, Vilkka V, Laurikainen K, Silvasti M, et al. Comparison of a novel salbutamol multidose powder inhaler with a salbutamol metered dose inhaler in patients with asthma. Curr Therap Res 1997;58:734-44

56 Thompson P. Cumulative dose-response trial of airomir (salbutamol sulphate in CFC-free system) versus CFC salbutamol sulphate and HFA-134a placebo in patients with asthma. Br J Clin Prac 1995;49(suppl 79):31-2.

57 Tinkelman DG, Bleecker ER, Ramsdell J, Ekholm BP, Klinger NM, Colice GL, et al. Proventil HFA and Ventolin have similar safety profiles during regular use. Chest 1998;113:290-6.

58 Tukiainen H, Terho EO. Comparison of inhaled salbutamol powder and aerosol in asthmatic patients with low peak expiratory flow level. Eur J Clin Pharmacol 1985;27:645-7.

59 Vidgren M, Silvasti M, Korhonen P, Kinkelin A, Frischer B, Stern K. Clinical equivalence of a novel multiple dose powder inhaler versus a conventional metered dose inhaler on bronchodilating effects of salbutamol. Arzneimittelforschung 1995;45:44-7.

60 Villiger B, Schwarz F. Comparison of inhaled terbutaline either via MD or via a new DPI Turbuhaler. Eur Respir J 1990;3:94s.

61 Waterhouse JC, Simmons JL, Wray H, Howard P. Comparative assessment of a new breath-actuated inhaler in patients with reversible airways obstruction. Respiration 1992;59:155-8.

62 Zainudin BMZ, Biddiscombe M, Tolfree SEJ, Short M, Spiro SG Comparison of bronchodilator responses and deposition patterns of salbutamol inhaled from a pressurized metered dose inhaler, as a dry powder, and as a nebulized solution. Thorax 1990;45:469-73.

63 Bronsky EA, Spector SL, Pearlman DS, Justus SE, Bishop AL. Albuterol aerosol versus albuterol Rotacaps in exercise-induced bronchospasm in children. J Asthma 1995;32:207-14.

64 Colice GL, Klinger NM, Ekholm BP, Dockhorn RJ. Proventil HFA prevents exercise-induced bronchoconstriction in children. J Asthma 1999;36:671-6.

65 Croner S, Hedenskog S, Kjellman NI, Oderlram H. Salbutamol by powder or spray inhalation in childhood asthma. Allergy 1980;35:589-92.

66 Custovic A, Taggart SC, Stuart A, Robinson A, Woodcock A. Efficacy of a new non-ozone depleting formulation for salbutamol. J Pharm Med 1995;5:161-8.

67 Fuglsang G, Pedersen S. Comparison of a new multidose powder inhaler with a pressurized aerosol in children with asthma. Pediatr Pulmonol 1989;7:112-5

68 Hirsch T, Peter-Kern M, Koch R, Leupold W. Influence of inspiratory capacity on bronchodilation via Turbuhaler or pressurized metered-dose inhaler in asthmatic children. Respir Med 1997;91:341-6.

69 Hultquist C, Ahlstrom H, Kjellman NM, Malmqvist LA, Svenonius E, Melin S. A double-blind comparison between a new multi-dose powder 
inhaler (Turbuhaler) and metered dose inhaler in children with asthma. Allergy 1989;44:467-70.

70 Kemp JP, Furukawa CT, Bronsky EA, Grossman J, Lemanske RF Mansfield LE, et al. Albuterol treatment for children with asthma: a comparison of inhaled powder and aerosol. J Allergy Clin Immunol 1989;83:697-702.

71 Laberge S, Spier S, Drblik SP, Turgeon JP. Comparison of inhaled terbutaline administered by either the Turbuhaler dry powder or a metered-dose inhaler with spacer in preschool children with asthma. J Pediatrics 1994;124(5, Pt 1):815-7.

72 Razzouk H, dos Santos L, Giudicelli J, Queiros M, Chieira M, Castro A, et al. A comparison of the bronchodilatory effect of 50 and $100 \mu \mathrm{g}$ salbutamol via Turbuhaler and $100 \mu \mathrm{g}$ salbutamol via pressurized metered dose inhaler in children with stable asthma. Int J Pharm 1999;180:169-75.

73 Bronsky E, Ekholm BP, Klinger NM, Colice GL. Switching patients with asthma from chlorofluorocarbon (CFC) albuterol to hydrofluoroalkane134a (HFA) albuterol. J Asthma 1999;36:107-14.

74 Dockhorn R, Vanden Burgt JA, Ekholm BP, Donnell D, Cullen MT. Clinical equivalence of a novel non-chlorofluorocarbon-containing salbutamol sulfate metered-dose inhaler and a conventional chlorofluorocarbon inhaler in patients with asthma. J Allergy Clin Immunol 1995;96:50-6.

75 Hawksworth R, Sykes AP, Bogolubov M, Mant T, Stahl EG, Lee TH. Comparison of the bronchoprotective effect of single doses of albuterol/HFA 134a and albuterol/CFC against exercise induced bronchoconstriction. J Allergy Clin Immunol 1999;103:S129.

76 Kemp JP, Hill MR, Vaughan LM, Meltzer EO, Welch MJ, Ostrom NK. Pilo trial of bronchodilator response to inhaled albuterol delivered by metered-dose inhaler and a novel dry powder inhaler. Ann Allergy Asthm Immunol 1997;79:322-6.

77 Newhouse MT, Nantel NP, Chambers CB, Pratt B, Parry-Billings M. Clickhaler (a novel dry powder inhaler) provides similar bronchodilation to pressurized metered-dose inhaler, even at low flow rates. Chest 1999;115:952-6

78 Nelson H, Kemp J, Bieler S, Vaughan LM, Hill MR. Comparative efficacy and safety of albuterol sulfate Spiros inhaler and albuterol metered-dose inhaler in asthma. Chest 1999;115:329-35.
79 Nieminen NM, Vidgren M, Laurikainen K, Jarvinen M, Liippo K, Tammivaara R, et al. Easyhaler, a novel multiple dose powder inhale clinically equivalent to salbutamol metered dose inhaler and easier to use. Respiration 1994;61:37-41

80 Ramsdell JW, Klinger NM, Ekholm BP, Colice GL. Safety of long-term treatment with HFA albuterol. Chest 1999;115:945-51.

81 Seppala OP, Kari E, Elo E, Loyttyniemi E, Kunkel G. Comparison of the bronchodilating efficacies of a novel salbutamol metered dose powder inhaler and a pressurised metered dose aerosol with a spacer. Arzneimittelforschung 1998;48:919-23.

82 Silvasti M, Laurikainen K, Nieminen M, Jarvinen M, Liippo K, Tammivaara R, et al. Single dose comparison between a novel multiple dose powder inhaler and a conventional metered dose inhaler in asthmatic patients. Acta Therapeutica 1993;19:125-35.

83 Borgstrom L, Derom E, Stahl E, Wahlin-Boll E, Pauwels R. The inhalation device influences lung deposition and bronchodilating effect of terbutaline. Am J Respir Crit Care Med 1996;153:1636-40.

84 Geoffroy P, Lalonde RL, Ahrens R, Clarke W, Hill MR. Clinical comparability of albuterol delivered by the breath-actuated inhaler (Spiros) and albuterol by MDI in patients with asthma. Ann Allergy Asthma Immuno 1999;82:377-82.

85 Langley SJ, Masterton CM, Batty EP, Jones M, Sykes A, Bogolubov M, et al. Comparison of single doses of HFA-134a propellant and CFC salbutamol in mild to moderate asthmatic patients. Eur Respir $J$ 1998;12(suppl 28):67S.

86 Hindle M, Newton DAG, Chrystyn H. Dry powder inhalers are bioequivalent to metered dose inhalers. Chest 1995;107:629-33.

87 Cleophas TJ. Carry-over biases in clinical pharmacology. Eur J Clin Chem Clin Biochem 1993;31:803-9.

88 Sellroos O, Pietinalho A, Riska H. Delivery devices for asthma medication. Clinical implications of differences in effectiveness. Clin Immunotherapy 1996;6:273-99.

89 Guyatt GH, Juniper EF, Walter SD, Griffith LE, Goldstein RS. Interpreting treatment effects in randomised trials. BMJ 1998;316:690-3.

(Accepted 11 July 2001) 